Case Report

\title{
Osseous Choristoma of the Tongue: A Review of Etiopathogenesis
}

\author{
Edoardo Gorini, ${ }^{1}$ Mauro Mullace, ${ }^{1}$ Luca Migliorini, ${ }^{2}$ and Emilio Mevio ${ }^{1}$ \\ ${ }^{1}$ Department of Otorhinolaryngology, Ospedale Fornaroli, Via Donatore del Sangue, 20013 Magenta, Italy \\ ${ }^{2}$ Department of Pathology, Ospedale Fornaroli, Via Donatore del Sangue, 20013 Magenta, Italy \\ Correspondence should be addressed to Emilio Mevio; emevio@libero.it
}

Received 26 August 2014; Accepted 30 October 2014; Published 14 December 2014

Academic Editor: Abrão Rapoport

Copyright (c) 2014 Edoardo Gorini et al. This is an open access article distributed under the Creative Commons Attribution License, which permits unrestricted use, distribution, and reproduction in any medium, provided the original work is properly cited.

\begin{abstract}
Osseous choristoma is a normal bone tissue in an ectopic position. In the oral region lingual localization occurs more frequently and the mass is generally localized on the dorsum of the tongue. Definitive diagnosis is obtained only after histopathologic examination. The etiology remains already debatable. The treatment of choice is surgical excision. In this paper we present a case of tongue osseous choristoma and a review of the literature.
\end{abstract}

\section{Introduction}

The term choristoma is used to describe the growth of normal tissue in an abnormal position. Choristoma of the mouth may be composed of several different tissue types. These include bone, cartilage, gastric mucosa, glial tissue, and tumor-like masses of sebaceous glands. Osseous choristoma is a well circumscribed benign growth of normal, mature osseous tissue in ectopic sites.

Osseous choristoma of the tongue is an extremely rare condition, of which only 66 cases have been reported in the literature till now. The osseous histotype is the most frequently described among choristomas. In the oral region lingual localization occurs more frequently and the mass is generally localized on the dorsum of the tongue. The etiology remains already debatable. The treatment of choice is surgical excision.

\section{Case Report}

A 10-year-old girl was referred to our ENT unit for a whitish $1 \mathrm{~cm}$ sessile swelling of the paramedian dorsum of the tongue, near foramen caecum (Figure 1). Upon palpation this not ulcerated lesion was firm. The patient did not complain of any symptom for many years. In the last two months she complained of lump. The mother of the girl reported that she noticed the little swelling since first months of life. She underwent neck ultrasound that showed a normal thyroid gland in shape and position. Although she was paucisymptomatic we proposed and performed a surgical excision of the lesion in order to obtain a histological diagnosis. Histological examination described an osseous choristoma of the tongue. The specimen was totally included for histological examination. Histologically, it appeared as a polypoid nodule of cortical bone tissue ( $\mathrm{mm} 10$ in maximum diameter) beneath the mucous membrane of the tongue covered by orthokeratinised squamous epithelium. The bone tissue was lamellar type with well developed haversian systems. The bone tissue was with sharply demarcated edges and in the surrounding tissue there was no inflammation or scar tissue (Figure 2).

After 1-year follow-up there is no evidence of recurrence.

\section{Discussion and Review of the Literature}

The term osseous choristoma was introduced by Krolls et al. in 1971 [1]. By definition it is a growth of normal tissue in an abnormal position. Choristoma of the mouth may be composed of several different tissue types. These include bone, cartilage, gastric mucosa, glial tissue, and tumor-like masses of sebaceous glands $[2,3]$.

Osseous choristoma of the tongue is an extremely rare condition. In the literature 66 cases have been described 
TABLE 1

\begin{tabular}{|c|c|c|c|c|c|}
\hline & Author & Age (y)/sex & Location & Size & Symptom \\
\hline 1 & Cataldo et al. [4] & $39 / \mathrm{F}$ & Posterior tongue & $1 \mathrm{~cm} \varnothing$ & None \\
\hline 2 & Begel et al. [5] & $22 / \mathrm{F}$ & Area of CP & $1 \times 0,5 \mathrm{~cm}$ & Dysphagia \\
\hline 3 & Jahnke and Daly [6] & $22 / \mathrm{F}$ & Posterior to $\mathrm{CP}$ & $1,3 \times 0,8 \times 0,7 \mathrm{~cm}$ & Lump \\
\hline 4 & Kaye [7] & $26 / \mathrm{F}$ & Base of the tongue & $1 \times 1 \mathrm{~cm}$ & Lump \\
\hline 5 & Goldberg et al. [8] & $65 / \mathrm{M}$ & Lateral border & $1 \mathrm{~cm} \varnothing$ & None \\
\hline 6 & Krolls et al. [1] & $22 / \mathrm{F}$ & Anterior to $\mathrm{CP}$ & $0,75 \mathrm{~cm} \varnothing$ & None \\
\hline 7 & & $23 / \mathrm{M}$ & Area of FC & Un. & Un. \\
\hline 8 & & $73 / \mathrm{M}$ & Posterior tongue & Un. & Gagging \\
\hline 9 & & $9 / \mathrm{F}$ & Area of FC & Un. & Gagging \\
\hline 10 & & $25 / \mathrm{F}$ & Posterior tongue & $0,5 \mathrm{~cm} \varnothing$ & Un. \\
\hline 11 & & $11 / \mathrm{F}$ & Posterior tongue & $2 \mathrm{~cm} \varnothing$ & Un. \\
\hline 12 & & $23 / \mathrm{M}$ & Area of CP & $0,5 \times 0,5 \times 0,5 \mathrm{~cm}$ & None \\
\hline 13 & & $39 / \mathrm{M}$ & Area of CP & $0,6 \times 0,6 \mathrm{~cm}$ & None \\
\hline 14 & Singh and Doyle [9] & $14 / \mathrm{F}$ & Left border & Un. & Un. \\
\hline 15 & & $22 / \mathrm{F}$ & Area of CP & $0,5 \mathrm{~cm} \varnothing$ & None \\
\hline 16 & McClendon [10] & $15 / \mathrm{F}$ & Area of FC & $1,4 \times 0,6 \times 0,5 \mathrm{~cm}$ & None \\
\hline 17 & & $20 / \mathrm{M}$ & Right border & $0,7 \mathrm{~cm} \varnothing$ & None \\
\hline 18 & & $46 / \mathrm{F}$ & Area of FC & $0,6 \mathrm{~cm} \varnothing$ & None \\
\hline 19 & Patel and Dane [11] & $42 / \mathrm{M}$ & Lateral border & $1 \mathrm{~cm} \varnothing$ & None \\
\hline 20 & Engel and Cherrick [12] & $31 / \mathrm{M}$ & Mid third right border & $2 \mathrm{~cm} \varnothing$ & Lump \\
\hline 21 & Busuttil [13] & $8 / \mathrm{F}$ & Left border & Pea-sized & Lump \\
\hline 22 & Ohno et al. [14] & Un. & Dorsum of the root of the tongue & Un. & Un. \\
\hline 23 & Sugita et al. [15] & Un. & Un. & Un. & Un. \\
\hline 24 & Sato et al. [16] & Un. & Un. & Un. & Un. \\
\hline 25 & Esguep et al. [17] & $63 / \mathrm{F}$ & Right border & $0,5 \mathrm{~cm} \varnothing$ & Lump \\
\hline 26 & Wasserstein et al. [18] & $50 / \mathrm{F}$ & Mid third & $1,5 \times 0,75 \mathrm{~cm}$ & Lump \\
\hline 27 & Shimono et al. [19] & $37 / \mathrm{F}$ & Area of FC & $1,5 \times 1,5 \times 0,7 \mathrm{~cm}$ & Lump \\
\hline 28 & Main [20] & $54 / \mathrm{F}$ & Posterior to FC & $1,5 \mathrm{~cm} \varnothing$ & Lump \\
\hline 29 & Sheridan [21] & $20 / \mathrm{F}$ & Anterior to $\mathrm{CP}$ & $1 \mathrm{~cm} \varnothing$ & Lump \\
\hline 30 & Cabbabe et al. [22] & $5 / \mathrm{F}$ & Base of tongue & $0,6 \times 0,5 \times 0,3 \mathrm{~cm}$ & Lump \\
\hline 31 & Nash et al. [23] & $31 / \mathrm{M}$ & Right border & $2,5 \mathrm{~cm} \varnothing$ & None \\
\hline 32 & Weitzner [24] & $52 / \mathrm{F}$ & Mid third & Small nodule & None \\
\hline 33 & & $25 / \mathrm{F}$ & Posterior tongue & $0,8 \times 0,4 \times 0,4 \mathrm{~cm}$ & Lump \\
\hline 34 & & $27 / \mathrm{F}$ & Posterior tongue & $0,8 \times 0,7 \times 0,3 \mathrm{~cm}$ & Lump \\
\hline 35 & Tohill et al. [25] & $31 / \mathrm{F}$ & Anterior to $\mathrm{CP}$ & $1 \times 0,8 \times 0,7 \mathrm{~cm}$ & None \\
\hline 36 & Markaki et al. [26] & $25 / \mathrm{F}$ & Posterior to CP & $0,8 \times 0,4 \times 0,3 \mathrm{~cm}$ & Lump \\
\hline 37 & Van Der Wal and van der Waal [27] & $31 / \mathrm{F}$ & Area of FC & $1 \mathrm{~cm} \varnothing$ & Lump \\
\hline 38 & Cannon and Niparko [28] & $51 / \mathrm{F}$ & Posterior tongue & Un. & Lump \\
\hline 39 & Bernard et al. [29] & $21 / \mathrm{F}$ & Area of FC & $2 \mathrm{~cm} \varnothing$ & Lump \\
\hline 40 & Maqbool et al. [30] & $8 / \mathrm{F}$ & Right vallecula & $5 \times 4 \mathrm{~cm}$ & Dysphagia, distress \\
\hline 41 & Lutcavage and Fulbright [31] & $11 / \mathrm{F}$ & Posterior to FC & $1 \mathrm{~cm} \varnothing$ & Lump \\
\hline 42 & Ishikawa et al. [32] & $53 / \mathrm{F}$ & Area of FC & $0,8 \mathrm{~cm} \varnothing$ & Foreign body sensation \\
\hline 43 & & $5 / \mathrm{F}$ & Anterior to $\mathrm{CP}$ & $3 \mathrm{~mm} \varnothing$ & Lump \\
\hline 44 & Lee et al. [33] & $35 / \mathrm{M}$ & Lateral border & Un. & Lump \\
\hline 45 & Ngeow et al. [34] & Un. & Un. & Un. & Un. \\
\hline 46 & Manganaro [35] & Un. & Un. & Un. & Un. \\
\hline 47 & Vered et al. [36] & $44 / \mathrm{M}$ & Left border & $0,7 \times 0,7 \times 0,6 \mathrm{~cm}$ & Gagging, nausea, and dysphagia \\
\hline 48 & & $27 / M$ & Posterior to CP & $1 \times 0,5 \mathrm{~cm}$ & Pain, gagging \\
\hline 49 & Supiyaphun et al. [3] & $28 / \mathrm{F}$ & Area of FC & $1 \times 0,8 \times 0,6 \mathrm{~cm}$ & Throat irritation \\
\hline
\end{tabular}


TABle 1: Continued.

\begin{tabular}{|c|c|c|c|c|c|}
\hline & Author & Age $(y) / \operatorname{sex}$ & Location & Size & Symptom \\
\hline 50 & & $25 / \mathrm{F}$ & Area of FC & $0,7 \times 0,5 \times 0,4 \mathrm{~cm}$ & Lump \\
\hline 51 & & $9 / \mathrm{F}$ & Area of FC & $0,7 \times 0,6 \times 0,5 \mathrm{~cm}$ & None \\
\hline 52 & & $35 / \mathrm{F}$ & Area of FC & $0,7 \times 0,5 \times 0,5 \mathrm{~cm}$ & None \\
\hline 53 & & $27 / \mathrm{F}$ & Area of FC & $1,2 \times 0,9 \times 0,6 \mathrm{~cm}$ & None \\
\hline 54 & & $21 / \mathrm{F}$ & Area of FC & $1,5 \times 1,3 \times 0,8 \mathrm{~cm}$ & Lump \\
\hline 55 & & $22 / \mathrm{M}$ & Area of FC & $0,9 \times 0,8 \times 0,6 \mathrm{~cm}$ & None \\
\hline 56 & & $19 / \mathrm{F}$ & Area of FC & $1,1 \times 0,7 \times 0,7 \mathrm{~cm}$ & None \\
\hline 57 & Lin et al. [37] & Un. & Posterior tongue & Un. & Un. \\
\hline 58 & Horn et al. [38] & $11 / \mathrm{F}$ & Posterior tongue & Un. & Lump \\
\hline 59 & Benamer and Elmangoush [39] & $14 / \mathrm{F}$ & Mid third & $1 \mathrm{~cm} \varnothing$ & Lump \\
\hline 60 & Carvalho et al. [40] & $22 / \mathrm{F}$ & Posterior tongue & $1 \mathrm{~cm} \varnothing$ & None \\
\hline 61 & Andressakis et al. [2] & $72 / \mathrm{M}$ & Anterior to $\mathrm{CP}$ & $1,5 \times 1 \mathrm{~cm}$ & Pain dysphagia \\
\hline 62 & Naik et al. [41] & $25 / \mathrm{F}$ & Posterior tongue & $1,2 \times 1,1 \times 0,5 \mathrm{~cm}$ & Lump \\
\hline 63 & Chen et al. [42] & $57 / \mathrm{F}$ & Posterior tongue & $1 \mathrm{~cm} \varnothing$ & Lump, dysphagia, and odynophagia \\
\hline 64 & Spencer and Reed [43] & $11 / \mathrm{M}$ & Posterior tongue & $1,1 \times 0,9 \times 0,6 \mathrm{~cm}$ & None \\
\hline 65 & Lin et al. [44] & $15 / \mathrm{M}$ & Area of FC & $0,5 \times 0,5 \mathrm{~cm}$ & Lump \\
\hline 66 & Qin et al. [45] & Un. & Un. & Un. & Un. \\
\hline 67 & Present case & $10 / \mathrm{F}$ & Anterior to FC & $1 \mathrm{~cm} \varnothing$ & Lump \\
\hline
\end{tabular}

(CP: circumvallate papillae, FC: foramen caecum, and Un.: unknown).

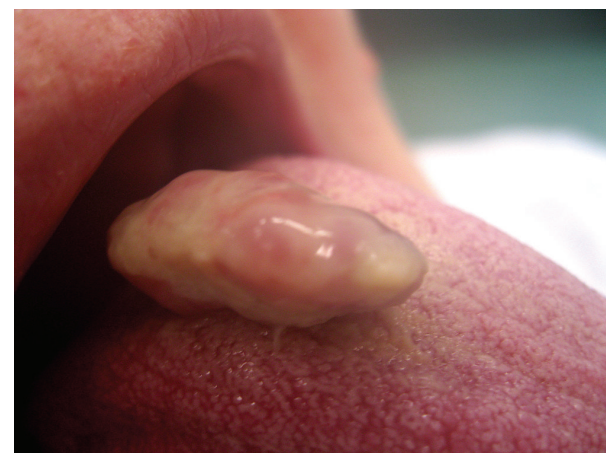

FIGURE 1: Paramedian dorsum of the tongue choristoma.

(Table 1) [1-45]. In our review the patient age ranged from five to seventy-three years (mean age: 28,7 years), with the majority of the patients being in the second or third decades of life. Choristomas of the tongue occur more frequently in women (M:F 16:44).

The most frequent affected region is the posterior third of the tongue dorsum near to the foramen caecum and circumvallate papillae. Pathogenesis of choristoma is still unknown and remains already debatable. Several theories tried to explain the pathogenesis of this disease. Some authors suggested that remnants of the undescended thyroid tissue might produce an osseous lesion but in some rare case choristoma is localized not in midline but on the border of the tongue [46]. In these cases some authors [36, 47] suggested a traumatic pathogenesis. They consider that the posterior third of the tongue is site of traumatic irritation by different lingual movement during swallowing and articulation and that frequent trauma leads to local inflammation with deposit

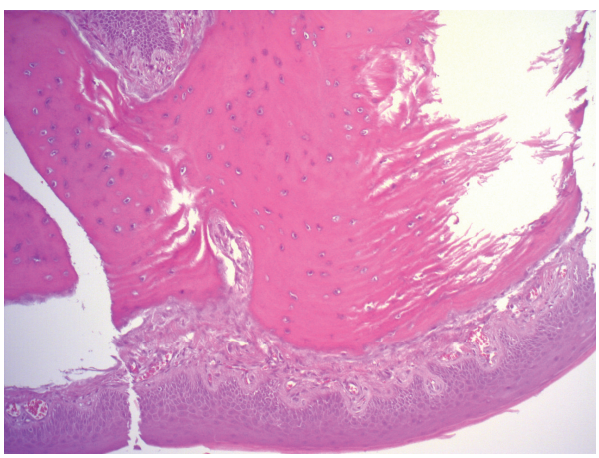

FIgURE 2: Histological examination shows mature lamella lined by mucous membrane of the tongue.

of calcium. This theory cannot explain the formation of osseous choristoma, because this lesion contains fully developed bone with haversian system and not just calcifications.

In our opinion embryologic theory sounds true. Embryologically the tongue is a very complex structure. First and third branchial arches give rise, respectively, to the anterior two-thirds and posterior third of the tongue. It was suggested that pluripotential cells from these arches give origin to the osseous choristoma $[5,12]$.

Choristoma appears as a sessile or pedunculated mass usually covered by normal mucosa. The sizes of the lesions vary from $3 \mathrm{~mm}$ to $50 \mathrm{~mm}$ at their largest diameter.

Most of osseous choristoma of the tongue presents as a frequently asymptomatic swelling. The most frequent symptom is lump (46\% of cases). Rarely patient complains of dysphagia (5 cases), gagging (4 cases), pain (4 cases), and nausea (1 case). Symptoms are correlated to lesion size, tumour 
localization, and surrounding tissues flogosis. The differential clinical diagnosis can be also based on the tumor location. When the lesion is located on the dorsal tongue near the foramen caecum we should consider in differential diagnosis benign tumours (hemangioma, lymphangioma, teratoma, hamartoma, and leiomyoma), thyroglossal duct cyst, lingual thyroid, mucocele, pyogenic granuloma, and malignant tumours (rhabdomyosarcoma, other sarcomas, and epidermoid carcinoma) [25]. Traumatic neuroma, neurofibroma, schwannoma, fibroma, and cartilaginous choristoma usually are located on the tongue margin. Pyogenic granuloma, mucocele, and cartilaginous choristoma frequently involve the anterior portion of the tongue. Nevertheless definitive diagnosis is obtained only after histopathologic examination.

The treatment of choice is surgical excision. Recurrence or malignant evolution has not been described.

\section{Conflict of Interests}

There are not present facts which may be considered as potential conflict of interests and significant financial contributions to this work. The authors wish to confirm that there is no known conflict of interests associated with this paper and there has been no significant financial support for this work that could have influenced its outcome.

\section{References}

[1] S. O. Krolls, J. R. Jacoway, and W. N. Alexander, "Osseous choristomas (osteomas) of intraoral soft tissues," Oral Surgery, Oral Medicine, Oral Pathology, vol. 32, no. 4, pp. 588-595, 1971.

[2] D. D. Andressakis, A. G. Pavlakis, E. Chrysomali, and A. D. Rapidis, "Infected lingual osseous choristoma. Report of a case and review of the literature," Medicina Oral, Patologia Oral y Cirugia Bucal, vol. 13, no. 10, pp. E627-E632, 2008.

[3] P. Supiyaphun, P. Sampatanakul, V. Kerekhanjanarong, P. Chawakitchareon, and V. Sastarasadhit, "Lingual osseous choristoma: a study of eight cases and review of the literature," Ear, Nose and Throat Journal, vol. 77, no. 4, pp. 316-325, 1998.

[4] E. Cataldo, G. Shklar, and I. Meyer, "Osteoma of the tongue," Archives of Otolaryngology, vol. 85, no. 2, pp. 202-206, 1967.

[5] H. Begel, H. Wilson, G. Stratigos, and R. F. Zambito, "Osteoma of the tongue: report of case," Journal of Oral Surgery, vol. 26, no. 10 , pp. 662-664, 1968.

[6] V. Jahnke and J. F. Daly, "Osteoma of the tongue," Journal of Laryngology and Otology, vol. 82, no. 3, pp. 273-275, 1968.

[7] W. H. Kaye, "Osteoma of the tongue," Journal of Laryngology and Otology, vol. 82, no. 3, pp. 269-271, 1968.

[8] A. F. Goldberg, D. F. Skuble, and R. J. Latronica, "Osteoma of the tongue: report of case," Journal of Oral Surgery, vol. 28, no. 6, article 457, 1970.

[9] S. M. Singh and J. L. Doyle, "Osteoma of the tongue. Two case reports," The New York State Dental Journal, vol. 38, no. 10, pp. 599-600, 1972.

[10] E. H. McClendon, "Lingual osseous choristoma: report of two cases," Oral Surgery Oral Medicine and Oral Pathology, vol. 39, no. 1, pp. 39-44, 1975.

[11] R. M. Patel and A. Dane, "Pathologic quiz case 1. Osteoma of the tongue," Archives of Otolaryngology, vol. 101, no. 4, pp. 266-268, 1975.
[12] P. Engel and H. M. Cherrick, "Extraosseous osteomas of the tongue," Journal of Oral Medicine, vol. 31, no. 4, pp. 99-103, 1976.

[13] A. Busuttil, "Clinical records. An osteoma of the tongue," Journal of Laryngology and Otology, vol. 91, no. 3, pp. 259-261, 1977.

[14] T. Ohno, H. Yanbe, E. Morii et al., "Osseous choristoma situated on the dorusum of the root of the tongue: report of a case," Japanese Journal of Oral and Maxillofacial Surgery, vol. 27, pp. 1106-1109, 1981.

[15] H. Sugita, E. Yamamoto, H. Sunakawa et al., "Lingual osseous choristoma: report of a case," Japanese Journal of Oral and Maxillofacial Surgery, vol. 25, pp. 165-169, 1979.

[16] Y. Sato, S. Ozawa, N. Aria, I. Toguchi et al., "Choristoma of the tongue: report of a case," Japanese Journal of Oral and Maxillofacial Surgery, vol. 27, pp. 93-95, 1981.

[17] A. Esguep, E. Espinoza, and G. Diaz, "Lingual osteoma," Journal of Oral Medicine, vol. 37, no. 1, pp. 27-29, 1982.

[18] M. H. Wasserstein, M. SunderRaj, R. Jain, G. Yamane, and A. P. Chaudhry, "Lingual osseous choristoma," Journal of Oral Medicine, vol. 38, no. 3, pp. 87-89, 1983.

[19] M. Shimono, T. Tsuji, Y. Iguchi et al., "Lingual osseous choristoma. Report of 2 cases," International Journal of Oral Surgery, vol. 13, no. 4, pp. 355-359, 1984.

[20] D. M. Main, "Osseous polyp of the tongue: osteoma or choristoma?” British Dental Journal, vol. 156, no. 8, pp. 285-286, 1984.

[21] S. M. Sheridan, "Osseous choristoma: a report of two cases," British Journal of Oral and Maxillofacial Surgery, vol. 22, no. 2, pp. 99-102, 1984.

[22] E. B. Cabbabe, C. Sotelo-Avila, S. T. Moloney, and M. V. Makhlouf, "Osseous choristoma of the tongue," Annals of Plastic Surgery, vol. 16, no. 2, pp. 150-152, 1986.

[23] M. Nash, T. Harrison, P.-T. Lin, and F. E. Lucente, "Osteoma of the tongue," Ear, Nose and Throat Journal, vol. 68, no. 1, pp. 6365, 1989.

[24] S. Weitzner, "Osseous choristoma of the tongue," Southern Medical Journal, vol. 79, no. 1, pp. 69-70, 1986.

[25] M. J. Tohill, J. G. Green, and D. M. Cohen, "Intraoral osseous and cartilaginous choristomas: report of three cases and review of the literature," Oral Surgery, Oral Medicine, Oral Pathology, vol. 63, no. 4, pp. 506-510, 1987.

[26] S. Markaki, J. Gearty, and P. Markakis, "Osteoma of the tongue," British Journal of Oral and Maxillofacial Surgery, vol. 25, no. 1, pp. 79-82, 1987.

[27] N. van der Wal and I. van der Waal, "Osteoma or chondroma of the tongue; A clinical and postmortem study," International Journal of Oral and Maxillofacial Surgery, vol. 16, no. 6, pp. 713717, 1987.

[28] S. C. Cannon and J. K. Niparko, "Pathologic quiz case 1. Lingual osteoma," Archives of Otolaryngology-Head \& Neck Surgery, vol. 114, no. 1, pp. 92-94, 1988.

[29] P. J. Bernard, J. M. A. Shugar, R. Mitnick, P. M. Som, and R. Meyer, "Lingual osteoma," Archives of Otolaryngology-Head and Neck Surgery, vol. 115, no. 8, pp. 989-990, 1989.

[30] M. Maqbool, R. Ahmad, and R. Ahmad, "Osteoma of the tongue: a rare cause of upper airway obstruction," Indian Pediatrics, vol. 29, no. 11, pp. 1429-1431, 1992.

[31] G. J. Lutcavage and D. K. Fulbright, "Osteoma of the tongue," Journal of Oral and Maxillofacial Surgery, vol. 51, no. 6, pp. 697699, 1993. 
[32] M. Ishikawa, T. Mizukoshi, K.-I. Notani, T. Iizuka, A. Amemiya, and H. Fukuda, "Osseous choristoma of the tongue. Report of two cases," Oral Surgery, Oral Medicine, Oral Pathology, vol. 76, no. 5, pp. 561-563, 1993.

[33] B. J. Lee, S. K. Ahn, S. H. Lee, and W. S. Lee, "Osteoma of the tongue," International Journal of Dermatology, vol. 33, no. 8, pp. 602-603, 1994.

[34] W. C. Ngeow, C. B. Lian, and P. Shanmahasuntharam, "Osseous choristoma of the tongue," The Journal of Nihon University School of Dentistry, vol. 38, no. 1, pp. 49-51, 1996.

[35] A. M. Manganaro, "Lingual osseous choristoma," General Dentistry, vol. 44, no. 5, pp. 430-431, 1996.

[36] M. Vered, J. P. Lustig, and A. Buchner, "Lingual osteoma: a debatable entity," Journal of Oral and Maxillofacial Surgery, vol. 56, no. 1, pp. 9-14, 1998.

[37] C. C. Lin, C. H. Chen, Y. K. Chen, Y. H. Shen, and L. M. Lin, "Osseous choristoma of oral cavity-report of two cases and review of the literature," The Kaohsiung Journal of Medical Sciences, vol. 14, no. 11, pp. 727-733, 1998.

[38] C. Horn, H. M. Thaker, D. A. Tampakopoulou, L. M. De Serres, J. L. Keller, and J. Haddad Jr., "Tongue lesions in the pediatric population," Otolaryngology-Head and Neck Surgery, vol. 124, no. 2, pp. 164-169, 2001.

[39] M. H. Benamer and A. M. Elmangoush, "Lingual osseous choristoma case report and review of literature," Libyan Journal of Medicine, vol. 2, pp. 46-48, 2007.

[40] L. Carvalho, L. Aurora, and M. Rabello, "Coristoma osseo lingual. A. Apresentacao de caso," Revista Brasileira de Odontologia, vol. 65, pp. 152-154, 2008.

[41] V. Naik, W. A. R. Wan Faiziah, and M. Musa, "Choristoma of the base of the tongue," Indian Journal of Pathology and Microbiology, vol. 52, no. 1, pp. 86-87, 2009.

[42] Y.-K. Chen, Y.-H. Shen, Y.-J. Lin, Y.-T. Li, K.-B. Tsai, and L.M. Lin, "Buccal osseous choristoma in a 5-year-old boy," Oral Oncology Extra, vol. 41, no. 9, pp. 198-201, 2005.

[43] J. C. Spencer and J. M. Reed, "Lingual osseous choristoma," in Proceedings of the Otorhinolaringology Annual Meeting, 2012.

[44] Y.-Z. Lin, C.-H. Hung, and S.-H. Hung, "Lingual osseous choristoma," Journal of Dental Sciences, vol. 8, no. 1, pp. 94-95, 2013.

[45] D. Qin, Y. Tang, D. Ren et al., "Tongue osteocartilaginous choristoma: a case report," Hua Xi Kou Qiang Yi Xue Za Zhi, vol. 32, pp. 96-98, 2014.

[46] M. Monsarrat, "Osteome de la langue," Bulletin de la Société D’Anatomie, vol. 88, pp. 282-283, 1913.

[47] J. J. Roy, H. Z. Klein, and D. L. Tipton, "Osteochondroma of the tongue," Archives of Pathology, vol. 89, no. 6, pp. 565-568, 1970. 


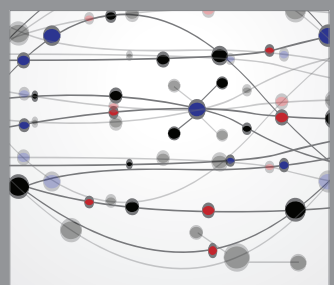

The Scientific World Journal
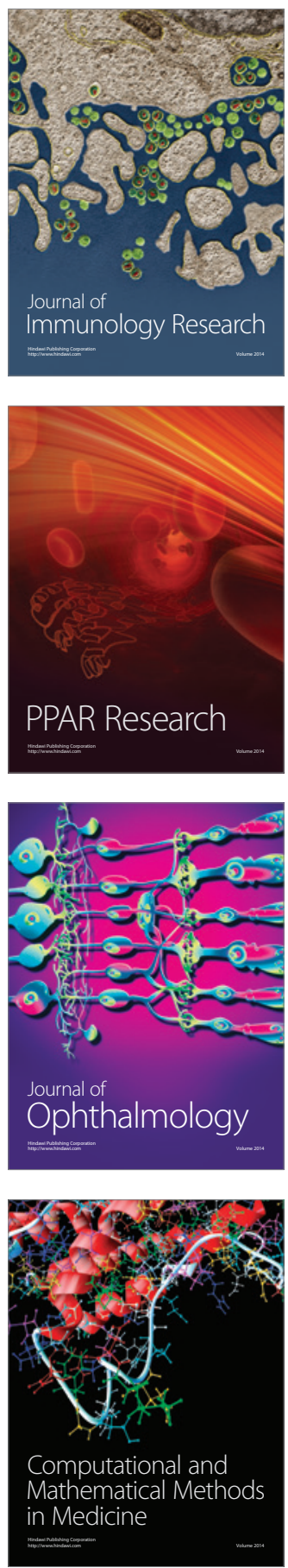

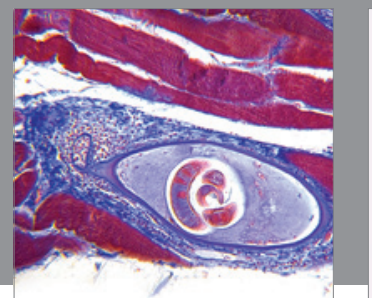

Gastroenterology

Research and Practice
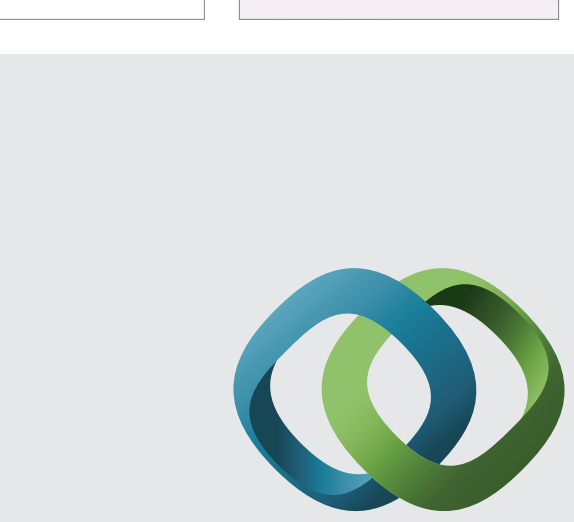

\section{Hindawi}

Submit your manuscripts at

http://www.hindawi.com
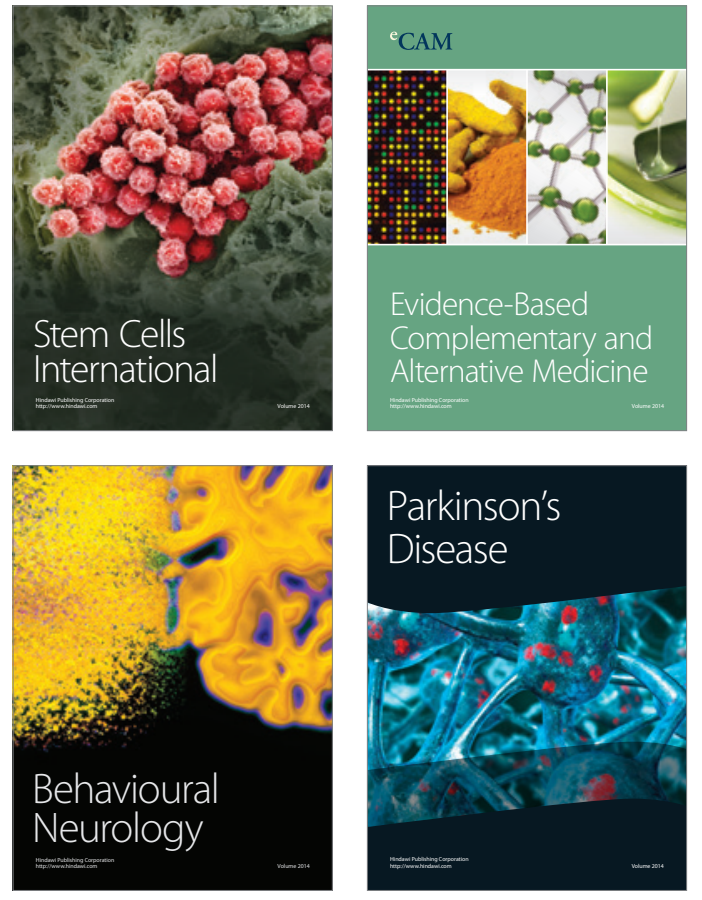
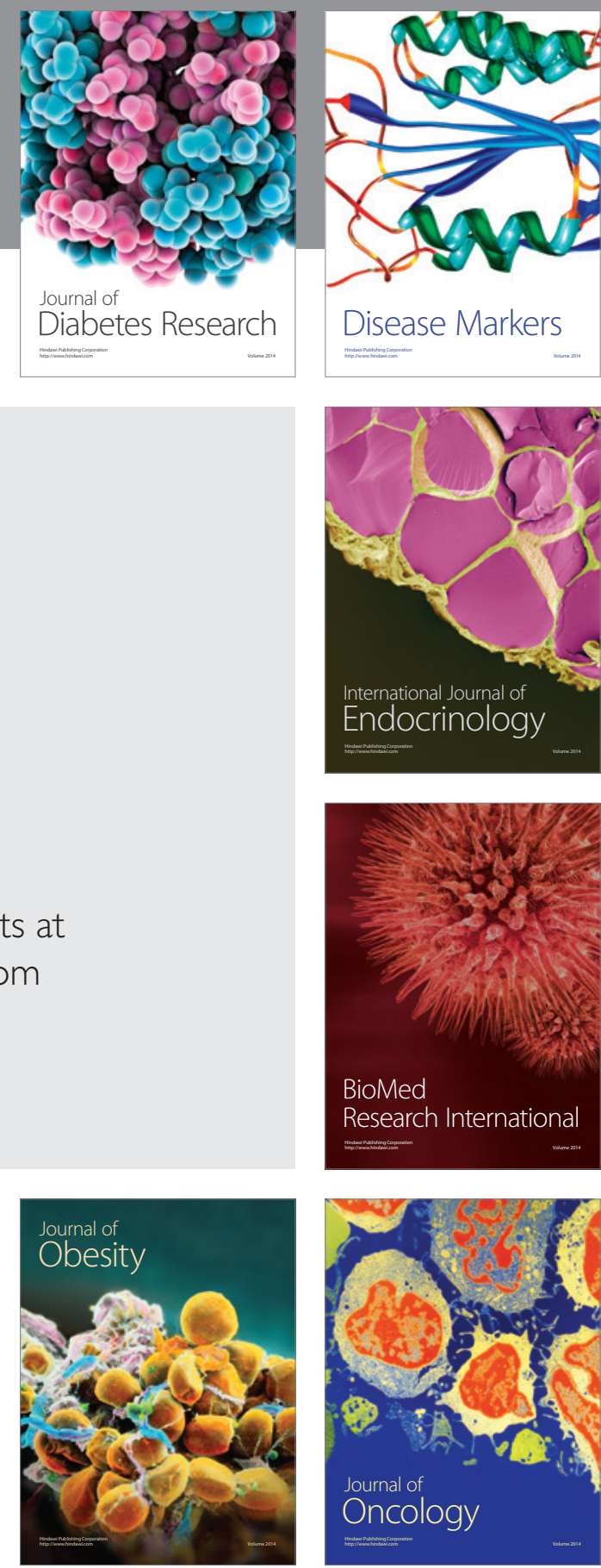

Disease Markers
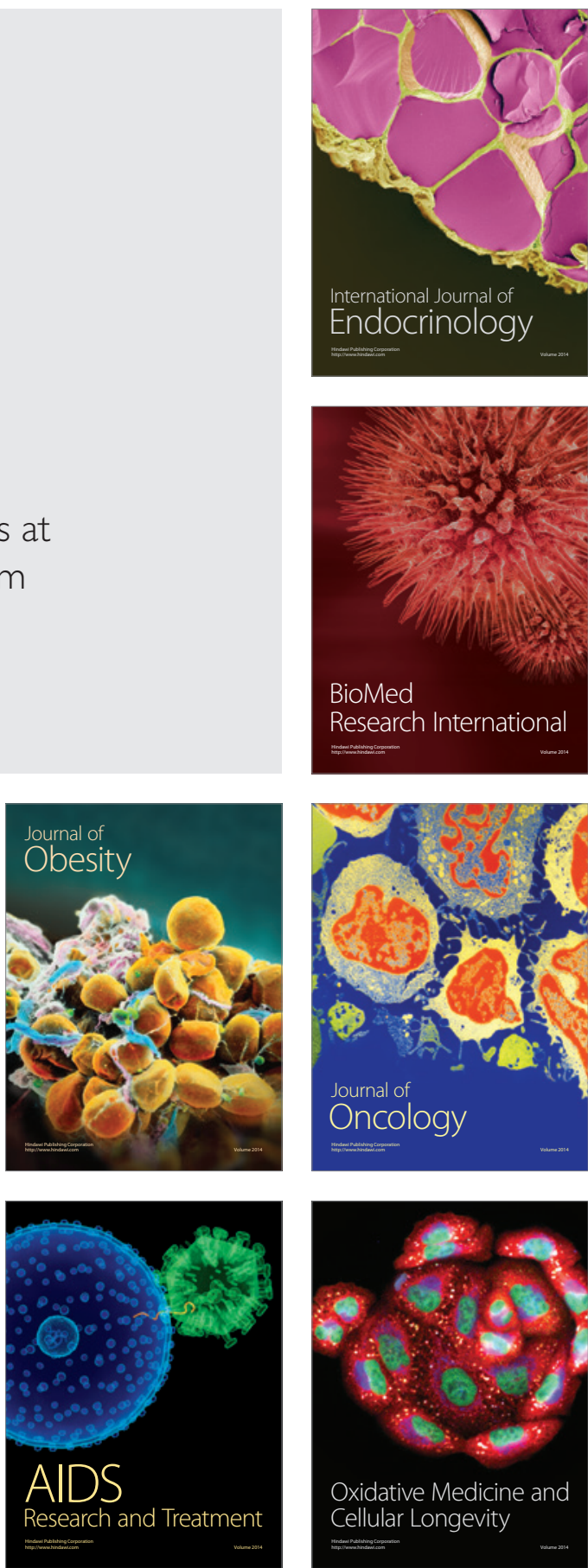